\title{
Urban Immunity Against the Pandemic within the Framework of Public Administration, City and Citizens ${ }^{1}$
}

\author{
Nilüfer Negiz \\ Süleyman Demirel University, Turkey \\ nilufernegiz@sdu.edu.tr \\ https://orcid.org/0000-0002-4211-9689 \\ Pınar Savaş-Yavuzçehre \\ Pamukkale University, Turkey \\ pyavuzcehre@pau.edu.tr \\ https://orcid.org/0000-0001-7726-1119
}

Received: 16. 2. 2021

Accepted: 11. 52021

\section{ABSTRACT}

The circumstances arising in connection with the Covid-19 pandemic indicate that outbreaks are inevitable and that new pandemics are quite likely. Cities, just like people, need to protect themselves from pandemics. Therefore, the existing urban and spatial practices should be reconsidered. The aim of the study is to explore, by observation and literature review, the cities' readiness for possible pandemics or emergencies within the framework of the concept of urban immunity. Based on the elements necessary for the provision of immunity in humans, the requirements for urban immunity, the health of the infrastructure and superstructure of the soil, the resources and sustainability of a city, its resilience and growth control are discussed within the framework of urban management. In addition, the study identifies three indispensable actors for urban immunity: i) central governments, ii) local governments, and iii) citizens. Immunized cities can be defined as cities with healthy infrastructure and superstructure factors of urban soil aiming at economic and ecological sustainability that have achieved a planned and controlled growth momentum, governed by public policies created with the understanding of local welfare and democracy in cooperation with local governments, citizens, and the central government. The study is purely theoretical and focuses on universal urban immunity rather than on any country example, which constitutes the strength of the study.

1 This article is a result of the project "The City During The Pandemic Process: A Study in Terms of Expectation-Capacity in Providing "Urban Immunity (Lakes Region Case)", No. 126K640, supported by the Scientific and Technological Research Council of Turkey. 
Keywords: urban immunity, immunized city, pandemic, Covid-19, local government, central government

JEL:R14, R28, R38, R52, Q58

\section{Introduction}

Throughout the last five centuries, humanity has established close ties between continents and cities. While these ties stimulate trade, relationships have been established and the groundwork has been laid for the spread of contagion. If all countries do not invest enough to prevent future pandemics, it is inevitable that the drawbacks will become too severe. This situation would cause less innovation in the world, less growth and much more suffering for the disadvantaged groups. Cities will be much less attractive to people if the threat of a possible future pandemic (s) is to be a permanent part of our existence (Glaeser, 2020). The cities need to be immune and be prepared like humans to be ready for future pandemics.

Epidemics are one of biological disasters. It is known that new infectious agents or controlled ones may cause outbreaks again due to many factors such as increasing anti-microbial resistance, ecological changes, chronic diseases, increasing poverty, malnutrition and weakening of the immune system due to infections such as HIV, climate change, rapid population movements, accessibility, coverage, and acceptability of basic health services (Şimşek, 2020, p.104). This situation forces countries to be prepared and resilient against these disasters. The ways to become immunized cities and countries by ensuring resilience and health should be discussed.

This research is based on the idea that the Covid-19 Pandemic chooses urban areas, and this study aimed to reveal how cities can become immune with the "Urban Immunity", "Immunized Cities" concepts both theoretically in the context of the physical and functional characteristics of the city and in the context of the assessments of the actors and citizens who manage these areas in order for the cities to be more prepared in the processes such as possible epidemic (s) and pandemic (s) that are experienced and may be experienced. In determining the health status of individuals living in a city, the physical, social, cultural, and economic conditions of the place they live are also important besides biological factors. For this reason, the health of the city is interdependent in terms of those living in the city, and the health of the city dweller in terms of the future of the city. In this context, by looking at the subject in terms of the city and the pandemic, the fundamental problematic of the pandemic "immunity" will be defined through the immunity of cities and discussed with its elements.

\section{Urban Immunity}

Immunity is defined as "resistance to disease, especially to infectious diseases". "The immune system is a collection of molecules-cells and tissues that 
provide resistance to infections. The coordinated reaction of this system against foreign molecules, such as microorganisms, is defined as the immune response." (Ankara Universitesi, 2020). Covid-19, a "new type" alien to human immunity, is a virus with a high level of destruction. The course of the disease, which results in death especially in individuals with weak immunity, has revealed the importance of the immune system of people. The main long-term struggle with the problem lies in reviewing our life and settlement forms and habits, and creating more resistant, safe, and "immune" living spaces and service processes against such viruses.

The Covid-19 pandemic has revealed the need for residential areas where people live to be immune to viral problems. There are opinions that accept cities as organisms that are born and develop and disappear over time, just like living beings. Among the urbanization theories, the Chicago School was inspired by the science of ecology and Darwin, while treating the city as a living organism and trying to define it (Wahl-Jorgensen, 2015; Serter, 2013, p.74). In this sense, the healthy functioning of all the structures that make up the city (this organism) is important for the development of the city (organism) and its survival. The basic element of the city is human. People living in healthy environments are related to the city, and the shaping of the city in a healthy structure is related to human health and resistant urban life with "high immunity". Cities and their health are on the agenda of the World Health Organization (WHO). "Healthy Cities Project" was developed in 1987. Almost every country of Europe and 53 countries from all over the world participated in this project.

The healthy city is a city that constantly creates and develops these physical and social environments and expands community resources that enable people to mutually support each other in fulfilling all the functions of life and developing their maximum potential. The aim of a healthy city is to create a health-supportive environment, to achieve a good quality of life, to provide basic sanitation and hygiene needs and to provide access to health services (WHO, 2020a). A healthy and active city is a city that constantly creates and develops opportunities in settled and social settings and expands community resources to ensure that all its citizens are physically active in their daily life (Belli, 2019, p.1938). In this study, urban immunity is defined by taking inspiration from the WHO's definition of a healthy city. Health is not just about the absence of a disease. It should also be carried out in cities in the context of general well-being, disease prevention-based service provision and living environment. Based on the relationship between human, healt and immunity; urban immunity can be defined as the resistance of cities to diseases. If the basic components of immunity for humans are the community of cells and tissues, then the actors of its immunity for cities are the main functions of the city and their management system. The predictions that the epidemic will change the planning and design, energy use, mobility models, housing preferences, green areas, and transportation systems in cities around the world (Üzümlüoğlu, 2020) reveal the importance of the sub-themes mentioned for the immunized city. 
Each author trying to define urban immunity with different factors. Chen and Hsu (2015, pp. 652-661) discuss urban immunity in terms of the response of the physical urban environment to external antigens. They list these antigens as follows: i) disasters caused by human or nature, ii) inappropriate urban plan/ design, iii) new human activities created by new technology. They have undertaken the scrutiny of the urban landscape in different scales with a morphological approach. As a result of research: If a balanced urban system disrupted by a significant event, the physical urban form would be impacted directly, and thus will transform to response to the change. After a series of transformation, the urban system can be steadied again. They regard immunity-based procedure, which can help an urban system evolve and therefore survive.

Bristow and Mohareb (2020, pp. 300-312)'s article examining the relationship between urban immunity system and climate change, identifying those attributes of the system that are expected to be of increasing importance under climate change. When discussing urban immunity against climate change, they question three factors for urban immunity. These are i) resistance of the built environment, ii) resistance to the cascade effects of failure, iii) recoverability. Dursun (2020), who made the proposition of urbanities that strengthen immunity with the approach of "cities are as strong as their individuals" based on the perspective of the citizens, set out from the necessity of constructing the immune system within the framework of stress management and active life (in terms of making exercise) apart from eating habits. Dursun has proposed an urban model, which has a positive effect on stress management and unwittingly exercising, both to strengthen the immune system of the urbanities and to facilitate the fight against the epidemic. The ideal starting point for this urban life form is at the neighborhood level and a walkable neighborhood design is offered. Neighborhoods are ideal areas for a healthy life with their parks, playgrounds, bicycle paths and all these functions designed for exercise. Healthier urban environments will be obtained when more space is allocated for uses such as pedestrian and bicycle paths and green areas. Another important urban regulation move is density balancing. For this purpose, solutions such as decentralizing the city and reducing the density are suggested.

\subsection{Elements of an immunized city}

The elements of immunity envisaged for human beings were considered within the context of the city, and the requirements that would make the city healthy and immune were adapted to the city. Each of the elements involved in human immunity is fictionalized for the city and arranged in a relational context. For the city, the organs of the body are matched to the upper and lower structure actors of the settlement. The sustainability of the body is matched to the sustainability of the city. Body resistance is matched to the elements that will make the city resilient. The nutrition of the body is matched to the city's resources. External factors that can harm the body are matched to the city's environment and growth. Finally, the self-management of the person (will), which will coordinate all these components, is matched to the management of the city and it is aimed to identify the sub-elements of urban immunity. 


\subsubsection{Health of the lower and upper structure of the soil}

The infrastructure of the city includes steps directly related to the planning of the city. Good planning is a major element of the city's health. In addition to the opening of a settlement for housing, it is an important urban component that is necessary for the healthy development and control of the housing after the settlement (Erdin, 2011, p.2). While aesthetics and functionality were established in harmony with nature, this understanding deteriorated after the industrial revolution. While the problems such as crowding, epidemics, air pollution and congestion caused by the increase in population and density in the industrialized western cities at the end of the 1800's caused misery in the cities, infrastructure investments also came to the fore in overcoming these problems. A healthy infrastructure has started to be emphasized with systems such as urban transportation, directing the settlement out of the center, electricity, sewerage, clean water and storing rainwater. The effort to overcome the negative effects of the industrial revolution in cities has formed the scientific theoretical basis of urban planning. Especially Ebenezer Howard's (1902) "Garden City" and Daniel Burnham's (Burgess, 1997) "City Beautiful" (movements appeared in these theories as the 19th century's solution proposals as urban life being intertwined with nature and the implementation of a series of physical arrangement tools.

Environmental problems have brought applications in harmony with nature in the theme of infrastructure in cities. Green infrastructure is a design that stands out in this sense. Green infrastructure is "a developing planning and design concept based on the idea of establishing a link between green areas and built infrastructure, which is especially based on hydrological networks, whose number is decreasing, but important in terms of fulfilling ecological functions" (Benedict and McMahon, 2006). The concept of urban green infrastructure expresses the whole of multi-functional natural, semi-natural and artificial ecological systems inside and outside the city (Yılmaz and Şahin, 2020, p. 328). Considering the ecological crises as well as the correct planning in the infrastructure elements of the city, we should act with a "green field" approach that is compatible with nature rather than aesthetics or profit.

Another important element in the city is the areas located on the ground; these areas are residences, public spaces, avenues, streets, squares, and green fields. The famous saying "Urban air frees people - Stadt luft macht frei" emphasizes the importance of cities in social life. The effects of cities on people's social life are extremely important. Streets, squares, parks, open spaces are areas of reconciliation where city dwellers can gather, meet, express themselves individually and together, and create urban culture. Urban spaces and the meanings attributed to these spaces are among the most important elements of communication between society and individuals.

These areas, which we define as the functions of the city on the ground and in the urban growth system, are as follows: central business and commercial zone, transition zone with trade and light industry establishments, low-quality housing spaces, high-quality housing spaces, suburbs, heavy industrial areas, 
and green areas (Keleş, 2016, p.126). In this context, the design of residential areas, public spaces and spaces is important. As the cities grow, the need for more housing and more residential areas arises with the crowding. With the increasing population, the most important problem area is the urban density and the rise of housing supply. Residential areas and high-rise buildings that are far from green between building blocks should be redesigned for our near future, which requires a distant life. The need to stay away from the indoor spaces that come together obliges outdoor spaces to stand out in urban design. For this reason, reconsidering social areas and residential areas, which аге on the ground as well as infrastructure and offered to the use of citizens, for a healthy and immunized city should be included in plans.

\subsubsection{Resources of the city and sustainability of the city}

The local reflection of the concept of economy, which refers to activities carried out to meet human needs, is "local economy" and operates in cooperation between socio-economic actors such as labor and employer organizations and local governments (Zengin et al., 2014, p.108). Development, which we can call as the developments in the general economic structure of the country, is expressed as national development. Subcomponents of national development are regional and local development. Local development is an understanding that offers the local area / region / district the opportunity to shape its own economic future. Planning and supporting the local economy, considering the needs and potential of the region, is possible with strong national economy and strategies. The relationship between the economy and development cycle in the course from micro scale to macro scale has been constructed with a bond that supports and nurtures each other. The first step will also be taken to ensure total development when the existing resources and potentials of the local population turn into good economic indicators (income, employment, etc.). In the steps to be taken for the development move, the extent to which the local resources are used sustainably is the main problem for the future of the city, the health and immunity of the city.

Cities are areas that contain natural structures and systems and where natural structures interact with each other. The natural resources of cities and their potential to generate income and employment by transferring them to the economy damage the ecosystem of the city. The mines and marble quarries, gold exploration studies, thermal power plants are the first applications that come to mind in this sense especially in developing countries.

The concept of "sustainable urban development", as it is most mentioned in the sustainability and urbanization literature, was first defined in 1996 in the final declaration of the United Nations Istanbul Habitat II Summit. Sustainable human settlements are defined as follows: "As we enter the twenty-first centu$r y$, we encourage a positive vision for sustainable human settlements, a sense of hope for our common future, and a fully beneficial and engaging challenge where everyone can live in a safe home that promises a decent life full of dignity, health, safety, happiness and hope" (Birleşmiş Milletler, 1996). The aim of sustainable urban development has emerged and spawned numerous urban settlement 
theories, including the "Healthy City", "Sustainable City", "Low-Carbon City", "Transit-Oriented City", "Compact City", "Smart City", "Green City", and "Livable City". The concept of the "Healthy City" is used in the field of public sanitation and city design. A Healthy City will bring many benefits, such as "a clean, safe physical environment of high quality", "the meeting of basic needs for all the city's people", and "an ecosystem that is stable now and sustainable in the long term" (Tang and Lee, 2016, p. 3).

Rapid growth threatens the sustainability of cities and the quality of urban life. Mass urbanization leads to social instability, undermining the capacity of cities to be environmentally sustainable and economically successful. A new sustainability model is needed, with more incentives to save energy, reduce consumption and protect the environment. The cities of the future should be socially different environments where economic and social activities overlap, and communities are concentrated around neighborhoods. The cities of the future should be developed or adapted to ensure that their citizens are socio-economically creative and productive (Riffat et al., 2016, p.1; Nijkamp and Perrels, 1994, p. 28).

\subsubsection{Urban resilience and strengthening of the city}

Urban immunity can be attributed to the fact that the city is resilient in the face of big global issues that it is not used to. The concept of "urban resilience" is a common concept used in the implementation of global policies including Agenda 2030 (Sustainable Development Goals), Paris Agreement and New Urban Agenda as a response to major global issues such as urbanization, development, climate change and sustainability. Urban resilience is 'the capacity of urban systems, communities, individuals, organisations and businesses to recover maintain their function and thrive in the aftermath of a shock or a stress, regardless its impact, frequency or magnitude' (Resilient Europe, 2016, p. 6). The Covid-19 pandemic caught all the countries of the world off guard as a global issue in this sense. Countries that have taken early and drastic measures in this process, which Wuhan is one of them, have worked more effectively to combat the epidemic. The focus of urban resilience is managing disaster risk and the effects of climate change. Economic crises, pandemics and uncontrolled urbanization have shown how a city can affect its ability to sustain growth and provide services to its citizens and have increased the need for Resilient Cities. In the face of the challenges faced by cities with urban resistance, it is aimed to maintain the old state of cities as well as to adapt and change to the new situation.

For humans, resilience refers to support and lifestyle, such as regular sleep, good nutrition, regular exercise, and vaccination, while for the city, resilience refers to strengthening its existing functions and environmental factors holistically. With this sense, the capacity to adapt to new formations should be considered both in new physical formations for the city and in the sense of improving existing ones.

Strengthening the city is possible by renewing the functions of the city, keeping them healthy and supporting them. The existence of building groups or 
spaces that have deteriorated or lost their function in the urban living space can cause urban diseases and harm the citizens. For this reason, just as healthy nutrition and vitamin or drug support are required to strengthen the body, it is necessary to improve the health and strengthen the immunity of places or environments that become dysfunctional at regular intervals for cities.

\subsubsection{Control of growth}

Rapid urbanization and urban sprawl are a worldwide phenomenon Such a growth brings along many problems such as congestion in cities, increase in the use of fossil fuels, an understanding of consumption dependent on nonrenewable resources, unconscious use of resources, air pollution, water pollution, soil pollution, noise pollution and above all, climatic anomalies. Naturally, ecosystems in and around urban settlements are directly affected by this growth. The process of urbanization and growth of cities that started after the industrial revolution in the world continues.

Until the early 1980s, a single-center city model was used to explain the spatial structure of cities. This model explains a growth approach that explains that all social and economic activities are concentrated in the "central business area", which is the only focus area, and that most residential areas are located in the city periphery. After the 1980s, new growth areas were formed in cities because of the spread of functions based on economic activity and skilled labor due to the changes in the spatial structure of metropolitan cities, the differentiation in lifestyles and the increasing number of immigrants (Sat et al., 2017, pp. 99-100). Thus, multi-centered cities, where several new centers were formed on the line extending from a single center to the periphery of the city, began to take shape as a new city form. At this point, 21st century cities are in the form of multicentric cities that show the characteristics of decentralization of economic activities, increasing mobility, mutual commuting, and spatial fragmentation of complex activities (Sat et al., 2017, pp. 99-101).

Urban growth must be controlled through development plans appropriate for the city's immunity. This requires reflection on urban growth management models. It is stated that the growth of the city is directed without adversely affecting the welfare of the individual and society by providing sustainable and efficient land use, sufficient green areas per person, effective access and transportation network, and sufficient equipment area (Seydanlıŏlu and Turgut, 2017, p. 437). In addition to determining the growth locations and quantities of the city and preparing appropriate urban development plans in the future, the control of growth is also beneficial in environmental and socioeconomic terms. Therefore, forecasting urban growth reveals the necessity of preparing urban growth management plans for all cities.

\subsubsection{Administration of the city}

While local governments are complementary to the central administration in unitary structed states; they have political and financial autonomy in states with a federative nature. The fact that the city is governed by elected local 
representatives ensures the functioning of democracy at the city level. The relationship between central administration and city administration can be examined as administrative, financial, and political relations. When regulating central-local relations, the authority of administrative guardianship must be limited to legal supervision in central governments. It is expected that local governments, as the closest service units to the citizen, will better identify and present the needs of the city.

The design of the urban area and the activation of all the sub-factors mentioned are based on the city administration in terms of ensuring urban immunity. Municipalities are the stakeholders of the local development of the city for employment and economic prosperity, the actor of the urban design with the responsibilities of the plan and implementation of the infrastructure and superstructure of the city, the stakeholder of the resilient city with the responsibility to renew the old and deteriorated areas and the spatial coordinators of this growth in the growth of the city. With all these responsibilities, local governments play an important role in viral epidemics such as Covid-19, as the closest management units to the city dwellers.

Special approaches are needed as each city has certain sustainability characteristics resulting from its geographical location as well as its political, social, physical, economic, and cultural conditions (Jones, 2010, p. 12). For this reason, the point that should not be forgotten when discussing the Covid pandemic over health is the fact that Covid chose cities. With this reality, city and urban policies should be re-evaluated in this process.

\section{Indispensable Actors for Providing Urban Immunity}

Urban immunity was defined in this study to adapt immunity, which is the basic concept of health science, to the city. A correct definition and discussion from the human-health relationship to the city-health relationship has been attempted to be made through the concept of "immunity". Based on what happened during the pandemic process, the issue has been addressed in the national framework within the following actors: i) central government, ii) local governments and iii) citizens.

\subsection{Central government}

Public policy is everything the state intends to do or chooses not to do (Dye, 1998, p. 3). All transactions and activities carried out by public institutions should be carried out within the scope of a certain public policy. Therefore, the extraordinary periods and crises caused by epidemics also lead states to question their capacities and public policy making processes again. As a result of the interrogations, it is seen that strong state capacity is the decisive factor in the success of crisis management. In order to talk about strong state capacity, many elements such as reliable political leadership, health, economy, supply chain, education, scientific research, transportation, effective management, digitalization, a well-functioning bureaucracy, properly and reliably 
executed communication skills should be carried out successfully (YIldız and Uzun, 2020). The government leaders need to develop a common understanding of the crisis through effective communication during crisis process.

States should design and implement both short (first phase) and medium and long term (second phase) public policies against earthquakes and epidemics. With reactive crisis management, it is aimed to solve the daily problems caused by the crisis in the short term before they grow. With proactive measures, efforts are made to eliminate the situation that caused the crisis in the medium and long term and to prevent it from happening again. With the Covid-19 pandemic, which is a global crisis, many countries had to implement reactive public policies in order to slow the spread of the disease, to gain time to improve health sector capacity, to reduce the number of deaths, to increase the morale of the society in the fight against the epidemic, and not to disrupt the functioning of the economy and the provision of basic public services (YIldız and Uzun, 2020, p.10). In the proactive approach stage, it is necessary to get to the root of the epidemic problem. As of February 2021, the second stage has not yet been passed. The timing, scope and impact of the measures taken by each country in the face of global situations differ from each other.

WHO encourages all countries to establish national epidemic prevention strategic plans and establish pandemic control committees. WHO has listed first emergency preparedness policies in combating the epidemic to reduce the risk and be prepared against such extraordinary periods that countries may encounter (WHO, 2018a, 2018b, 2020a, 2020b). Coordination and control of healthcare management is important after evaluating the risk and severity during the epidemic process. In this process, the central government should plan the inter-agency communication processes well and execute them effectively. There are the following stages in combating the epidemic: controlling the spread of the disease, ensuring sustainability in other public services, informing the public and finally post-epidemic assessment.

It is extremely important to guide the community and health workers to manage such an epidemic correctly on a global scale. In epidemics, societies are in a state of panic and they want to get information as quickly as possible. Therefore, it is important to provide reliable sources of information. In addition, proper management of health workers and knowledge of the basic principles of infection control will reduce the burden of both infection control teams and infectious disease doctors (Kutlu, 2020, p. 331). The central government should regularly and transparently share all data from the center to protect the public from information pollution during times of emergency. Communication must be carried out effectively to promote public understanding, trust, and compliance with the measures.

\subsection{Local governments}

Cities and urban services are one of the most important elements in ensuring urban immunity. Cities are the application areas of public policies. Cities are undoubtedly the most important actors of the locality with their legal person- 
ality and partial autonomy, in cooperation with the central government. After the public policies determined by the central administration gain identity through laws, they show a flow from the center to the local within the administrative system. The importance of public policies in the city during the pandemic period is based on the close relationship between public policies and people's behavior. The pandemic has required policy implementations that include fast, sharp, and tough decisions in the context of public policy. When the relationship between public health and land use is well coordinated, the suggestion can be put forward that pandemics can be better prepared (Özüduru, 2020, p. 12).

City plans are important for an immunized city. Problems that appear in the context of both spatial and urban life in which cities are located today can be associated with errors arising from the planning of the city's future. For the services carried out in cities to be carried out effectively and efficiently, cities are the subject of planning activities taking into account various factors such as economic, social, cultural, environmental and health. In the past, cities where fewer people lived in terms of population were settlements established to meet their basic needs such as protection and shelter. Today, cities have turned into social spaces where people live densely and where economic, political, cultural, and social needs are met, beyond just being physical structures that meet the need for shelter and security. Therefore, planning action for cities today appears as a complex and difficult process (Keleş, 2016, p.110). While physical, social, and economic factors were an important factor in the planning of a city for urban planners in the beginning, the creation of healthy cities has become an important agenda item in the last century, especially in the face of increasing environmental and ecological problems in urban space (Kenzer, 1999, p. 202).

The most effective activities in the pandemic process are conducted by local administrations as the closest service units to the citizen. Based on this, within the framework of the "Health in All Policies" approach of WHO (2020b), local governments, primarily responsible for cities, should plan their service processes with this understanding. In some countries, including Italy, because of the spread of the virus from one province to another, it was decided to give health, police, and emergency services to local governments.

For the pandemic that requires both short- and long-term policy responses, governments and development partners need to invest in strengthening local governments. (Rajadhyaksa, 2020). While municipalities performed routine services with their current budgets, more frequent cleaning and disinfection works and social assistance expenditures increased significantly during the pandemic period. In this process, there was a need to support municipalities in a financial sense.

In order to ensure urban immunity, i) local governments need to eliminate institutional overlaps, ii) local governments should encourage emergency preparedness, iii) local governments should develop cross-coordination and communication platforms and enhance integration to rapidly deploy citizens 
and resources where they are needed most; iv) experience in the SARS and Ebola outbreaks has shown that public actions lessened the impact of the crisis. Therefore, local governments should inform citizens, especially strong reliable people from among the population, such as clergymen, about this struggle and empower citizens v) local governments must have permanent resilience, a regular system, practices, and resource flow established in good times to work effectively in times of crisis (Rajadhyaksa, 2020). According to Sennet (2020), the pandemic is the time to fear the opportunity it offers for the ruling powers, to reject the panic theater staged in the media, to find ways to overcome the widening gap between a safe middle class and the emerging working class, and to explore forms of diversity. Local authorities should be able to use technology to connect the green city with the healthy city and validate the power of the community in the city.

Local governments need to develop preventive health services aimed at making people immune and resistant to diseases to create immunized cities. Investments should be made in infrastructure, education, awareness activities and public health. Alternative service models should be developed for possible crisis periods by prioritizing the duties and responsibilities of the institution included in the municipal laws. For instance, alternative transportation options should be created to be used in times of crisis against situations such as road infrastructure, bridges, and viaducts so that transportation services are not interrupted. To address the possible climate crisis in the coming years, investments should be made in environmentally friendly transportation models, pedestrian and bicycle priority roads should be designed.

During the pandemic period, the municipalities intensely carried out precaution and hygiene activities. Within the framework of becoming an immune city, there is a serious need for technology-facility investments especially in the collection, separation, disposal, and recovery of wastes. For the collection of medical waste such as masks and gloves, whose use is increasing with the pandemic, different garbage bins should be placed in every point of the city, and medical waste sterilization facilities should be established for their disposal.

In times of crisis, communication and power outage radios, mobile generators, mobile hospitals, and tents should be kept. Measures for other urban services (such as security) should be taken in coordination with other public actors in the province. In preparation for disasters, the public should be informed, and awareness should be raised about disasters and public health. Basic first aid courses can be an example of this. Municipalities can also establish call centers to provide psychological counseling.

In the face of the possibility of repeat epidemics, the ability and economic power of city managers and cities to adapt to the situation should be increased. In the pandemic process, it is vital to take measures to reduce the effects of the epidemic and to ensure the effective use of resources. For example, it is important to be able to easily create temporary housing and health centers and to have areas and spaces to build them. 
The Covid-19 pandemic has shown that the virus is spreading faster in large and well-connected cities if rapid and effective health measures are not taken. The city of New York in the USA and the city of Wuhan in China are examples of this with their crowded population (Constable, 2020). Taking strength from both technology and organizational structure, local governments should create a combination of healthy, resilient, smart, calm urban examples and even more prepared immune urban elements in their cities.

\subsection{Citizens}

The citizens, who are the main owners of the city partly directly, partly through elected organizations (local governments), form another pillar of the immunized city. Public policies established by the central government involving local citizens and urban services provided by local governments are entirely for citizens. Every citizen deserves a quality life. The expectations of each person living in the city from a quality life and the issues that are considered rights in this direction were determined by the European Urban Rights Charter at the European Conference of Local and Regional Governments. This charter is a recommendation for member countries. Urban rights included in the charter are rules that reflect the ideal conditions to be achieved. It cannot be said that all urban dwellers in many countries of the world, including the industrialized and wealthy countries, benefit from most of these rights adequately.

There is no agreed international text on what Urban rights are. The European Urban Charter, adopted by the European Commission in 1992, is considered as a starting point in this regard (Tekeli, 2011, p. 186). According to the European Urban Charter, the ideal city is defined as follows: "The ideal city is a place of residence that protects the rights of the city dwellers, offers the people a good life style by providing the best living conditions, and accommodates many sectors and activities (traffic, life, work, recreation needs) in harmony taking its value from those who live, visit, work and trade in this city, and meet their entertainment, culture and knowledge and education needs in this city ". It is primarily the duty of local administrations and the central government to ensure the urban rights of every segment of society. Strong and autonomous local governments that are aware of the responsibility of delivering the quality service that all people deserve are required for the protection and good functioning of the rights of the city in the urban system.

Urban rights are also important in terms of being a healthy and resilient city. Even if the city where a society is made up of people who do not have the rights specified in the Urban Condition has all the other components, the quality of being resistant or healthy is open to discussion. For cities to become immune to possible pandemics or disasters, human-oriented, human-glorifying urban models should be established, as well as smart cities that glorify technology, the network. In the face of threats such as the Fair City, which emphasizes social inequalities, the focus of the struggling city should also be on people. According to Lefebvre (2018, pp. 122-123), individuals with business lines such as architects, economists, sociologists do not have the power to create 
very meaningful, multi-sensory, transparent relations with their environment and themselves in the provision of urban rights. Only social life itself has this power. From this point of view, social life is important for the immunized city.

The problem concerns not only individuals but also the inability to control the capitalist order. However, the experienced disasters, crisis periods and pandemics have shown that the current urban situation is problematic for individuals. The concept that brings the citizens and urban space closer is the urban consciousness defined at the intersection point of urbanization, urbanity, and urban culture. Urbanity awareness means that the people living in the city know that they are a part of the city they live in and are aware of their responsibilities towards the city. Urbanity awareness is very important for the city to gain resistance or immunity. So much so that the citizen must fulfill his debts to the city as well as demand the rights of the urbanite. City dwellers should embrace the city and feel belonging to the city, participate in the decisions made and take part in the project development phase. To fulfill these, local administrations can organize activities, seminars, and trainings in coordination with non-governmental organizations and educational institutions in order to raise awareness of the public. By using social media effectively, local governments should inform the public of the projects they are pursuing and ensure they are involved in the process. Cultural policies and socio-cultural activities created considering the traditional and cultural characteristics of the city and the cultural character of the population increase the citizen's sense of belonging to the city. Awareness of urbanism or what needs to be done in extraordinary situations should be taught in the family and educational institutions starting from childhood.

\section{Conclusion}

Cities that have undergone changes and transformations under the influence of different variables for centuries are now undergoing extensive changes due to epidemics. The Covid-19 pandemic has led to a global crisis (s) in health, society, economy and many more areas. The prerequisite for the existence of cities today depends on their readiness and resilience in the face of future shocks. In this sense, it is important that cities are healthy, resistant, and immune. To ensure all these elements, all stakeholders, primarily public institutions, central administration and local governments, citizens, non-governmental organizations, and private sector, should work for the future of the globe, the future of the cities and the future of humanity.

The most important problem of city administrations in ensuring and maintaining urban immunity is urban growth. As emphasized in the urban-human immunity fiction, while the pests in the physical environment (virus, bacteria, etc.) that will harm the immune system of the people and enter the system from the outside, the biggest damage for the city is uncontrolled growth above what it should be. The density of cities is also the cause of many urban diseases. To change the existing urban density and settlement perception, it is necessary to focus on practices such as turning to horizontal architecture 
and increasing green spaces and public open spaces. Therefore, central, and local administrations should immediately put this issue on their agenda for the growth of cities and the solution of the problems experienced in the control and management of this growth.

In the face of extraordinary periods or disasters such as a pandemic, the strategies to be followed by the central administration before, during and after it, the institutions in charge, the resources to be provided, and the implementation regulation should be determined in detail. An interdisciplinary and integrated approach to the situation must be followed to make countries and cities immunized at national or urban level.

In this process, local governments should acquire qualifications that are participatory, embracing all segments of the society, democratic in decision making, using technology well, being a member of international city networks, benefiting from good experience sharing, and following the latest developments. To strengthen their capacity, municipalities should strengthen their institutional structures and invest in their stakeholders, personnel, movable and immovable equipment.

Arrangements to be made in urban spaces can be listed as follows: First of all, the public spaces, which are decreasing day by day, should be arranged for the use of the citizens in an easy and accessible way not for commercial and touristic rent purposes, but for the public benefit; pedestrianization in the city, that is, planning car-free zones, determining meeting places in times of crisis, street improvement and rehabilitation, arranging parks and sports areas, providing areas for local producers and establishing producer markets, promoting the local economy, arranging alternative transportation routes (such as bicycle paths), restoring historical buildings to the public and facilitating the access of disabled people to public spaces.

The urban dweller who has reached the awareness of urbanity must trust the public administration for the immunized city. If the public believes that the public administration is competent, fair, and honest in the face of emergencies and takes its side in its struggle, city immunity increases. In the public policies regarding the city to be created from the bottom up, the society should also demand and participate in the decisions taken.

In the face of possible pandemics, epidemics, disasters and crises, all actors in the global sense need to make efforts for urban immunity. The whole world needs to believe in this and work for heatthier and more resilient cities, especially public administration actors. A livable world for everyone should be created, starting from the local against global inequalities. 


\section{References}

Androniceanu, A. (2020). Major structural changes in the EU policies due to the problems and risks caused by COVID-19. Administratie si Management Public, 34, pp. 137-149. DOI: 10.24818/amp/2020.34-08.

Ankara Üniversitesi. Ders Kategorileri. At <https://acikders.ankara.edu.tr/>, accessed 15 October 2020.

Belli, A. (2019). "Türkiye'de Sağlıklı Kentler ve Büyükşehir Belediyeleri Üzerine Karşılaştırmalı Bir Analiz". OPUS Uluslararası Toplum Araştırmaları Dergisi, 10(17), pp. 1930-1962.

Benedict, Mark A. and McMahon, E. (2006). Green Infrastructure: Linking Landscapes and Communities Illustrated Edition, Washington DC: Island Press.

Birleşmiş M. (1996). HABiTAT Gündemi ve İstanbul Deklarasyonu. At <https:// webdosya.csb.gov.tr/db/habitat/editordosya/file/dokumanlar/Istanbul\%20 Deklerasyonu.pdf>, accessed 25 November 2020.

Bristow, D.N. and Mohareb, E.A. (2020). From the urban metabolism to the urban immune system, Journal of Industrial Ecology, Vol 24, Issue 2, April 2020. At <https://doi.org/10.1111/jiec.12919>, accessed 1 May 2021.

Burgess, P. (1997). The Expert's Vision: The Role Of Design In The Historical Development Of City Planning, Journal of Architectural and Planning Research, 14(2), pp. 91-106, At <https://www.jstor.org/ stable/43029253?seq=1>, accessed 1 May 2021.

Chen, C.-H. and Hsu, L.-F. (2015). A study of immunity-based urban system: A morphological approach, Procedia Computer Science, 60, pp. 652-666.

Constable, H. (2020). Koronavirüs: Salgın Hastalıklara Karşı Nasıl Şehirler İnşa Edilebilir? At <https://www.bbc.com/turkce/haberler-dunya-52531299>, accessed 8 October 2020.

Dursun, D. (2020). Covid-19 Sonrası Şehirciliği Yeniden Ele Almak: Bağışıklık Güçlendiren Kentler. At <http://kenthali.org/yazi-detay.php?entry_id=48>, accessed 8 November 2020.

Dye, T. R. (1998). Understanding Public Policy. London: Prentice Hall.

Erdin, H. E. (2011). "Şehirsel Yerleşmelerde Teknik Altyapı Sorunlarının Proje Niteliklerini Belirleyen Ortak-Eşgüdümsel Değişkenlere Göre Değerlendirilmesi, Tire Belediyesi (İzmir) Örneği". Dokuz Eylül Üniversitesi Mühendislik Fakültesi Mühendislik Bilimleri Dergisi, 13(2), pp. 1-22.

Glaeser, E. L. (2020). Cities and Pandemics Have a Hong History. At <https:// www.city-journal.org/citiesand-pandemics-have-long-history>, accessed 3 July 2020.

Howard, E. (1902). Garden Cities of To-morrow! London: Swann Sonnenschein \& Co, 1898. Second edition of "To-morrow A Peaceful path to Real Reform, Paternoster Square At <https://babel.hathitrust.org/cgi/pt?id=hvd.32044029 579976\&view=1up\&seq=11>, accessed 1 May 2021.

Jones, H. (2020). Sustainability Reporting Matters: What Are National Governments Doing About It? At <https://research-repository.st-andrews. ac.uk/bitstream/handle/10023/3792/ACCA2010-Sustainability-Matters. pdf? sequence $=1>$, accessed 15 November 2020.

Keles, R. (2016). Kentleşme Politikası. Ankara: İmge Kitabevi.

Kenzer, M. (1999). Healthy Cities: A Guide To The Literature, Environment and Urbanization, 11(1), pp. 201-221. 
Kutlu, R. (2020). "Yeni Koronavirüs Pandemisi ile ilgili Öğrendiklerimiz, Tanı ve Tedavisindeki Güncel Yaklaşımlar ve Türkiye'deki Durum". Turkish Journal of Family Medicine and Primary Care, 14(2), pp. 329-344.

Lefebvre, H. (2018). Şehir Hakkı. İstanbul: Sel Yayıncılık.

Nijkamp, P. And Perrels, A. (1994). Sustainable Cities in Europe, A Comparative Analysis of Urban Energy-Environmental Policies. London: Earthscan Publications.

Özüduru, B. H. (2020). Covid-19 ve Şehirler. Ankara: IdealKent Yayınları.

Rajadhyaksha, M. (2020). As Governments Design National Level Responses to COVID-19, the Role of Local Government is Pivotal in Ensuring Implementation. At <https://www.opml.co.uk/blog/five-lessons-for-localgovernments-during-covid-19>, accessed 10 July 2020.

Resilient Europe. (2016). Urban Resilience: A concept for co-creating cities of the future. At <https://urbact.eu/sites/default/files/resilient_europe_baseline_ study.pdf>, accessed 2 May 2021

Riffat, S., Powell, R. and Aydin, D. (2016). "Future Cities and Environmental Sustainability". Future Cities and Environment, 2(1), 1.

Sat, A. et al. (2017). "Sürdürülebilir Kentler İçin Çok Merkezli Gelişme: Ankara Metropoliten Kenti için Bir Değerlendirme". Ankara Araştırmaları Dergisi, 5(1), pp. 98-107.

Sennett, R. (2020). "Cities in the Pandemic". At <https://www.publicspace.org/ multimedia/-/post/cities-in-the-pandemic>, accessed 24 August 2020.

Serter, G. (2013). "Şikago Okulu Kent Kuramı: Kentsel Ekolojik Kuram". Planlama Dergisi, 23(2), pp. 67-76.

Seydanlıoğlu, A. and Turgut, S. (2017). "Türkiye Kentleri İçin Kentsel Büyüme Yönetimi Sistemi ve İstanbul Örneği". Megaron, 12(3), pp. 429-442. doi:10.5505/megaron.2017.94547.

Şimşek, Z. (2020). «ßBiyolojik Afet Olarak Covid 19 Pandemisi Özelinde Mevsimlik Tarım İşücü ve Ailelerine Yönelik Temel Sağlık Hizmetlerinin Sunumu». Sağlık ve Toplum (Özel Sayı), pp. 103-111.

Tang, H.T. and Lee Y.M. (2016). The Making of Sustainable Urban Development: A Synthesis Framework, MDPI. Sustainability, 8(492), pp. 1-28.

Tekeli, ì. (2011). Kent, Kentli Hakları, Kentleşme ve Kentsel Dönüşüm Yazıları. Ankara: Tarih Vakfı Yurt Yayınları.

Üzümoğlu, T. (2020). WRI Türkiye Sürdürülebilir Şehirler'den Yaşanabilir Şehirler Forumu: COVID19 Daha Yaşanabilir ve Sürdürülebilir Kentler İçin Bir Fırsat! At <https://wrisehirler.org/haberler/wri-t\%C3\%BCrkiyes\%C3\%BCrd\%C3 \%BCr\%C3\%BClebilir-C5\%9Fehirler\%E2\%80\%99denya\%C5\%9Fanabilir\%C5\%9Fehirler-forumu-covid-19-daha>, accessed 9 October 2020.

Wahl-Jorgensen K. (2015). The Chicago School and Ecology: A Reappraisal for the Digital Era. American Behavioral Science, 60(1), pp. 8-23. At <https:// orca.cf.ac.uk/76783/1/Chicagoschool\%20ecology\%20final\%20accepted\%20 version.pdf>, accessed 3 May 2021.

World Health Organization. (2018a). Managing epidemics: key facts about major deadly diseases. At <https://apps.who.int/iris/handle/10665/272442>, accessed 1 May 2021.

World Health Organization (2018b). A checklist for pandemic influenza risk and impact management: building capacity for pandemic response. Geneva. At 
<https://www.who.int/influenza/preparedness/pandemic/PIRM_Checklist_ update2018.pdf>, accessed 1 May 2021.

World Health Organization (2020a). Types of Healthy Settings. At <https://www. who.int/healthy_settings/types/cities/en/\#: :text=Healthy\%20Cities,devel oping\%20to\%20their\%20maximum\%20pote>, accessed 5 October 2020.

World Health Organization (2020b). Health in All Policies: Framework for Country Action. At <https://www.who.int/healthpromotion/ frameworkforcountryaction/en/>, accessed 8 July 2020.

World Health Organization (2021). Countries. At <https://www.euro.who.int/en/ countries>, accessed 2 February 2021.

Yıldız, M. and Uzun, M. M. (2020). Koronavirüsle Mücadelede Kriz Yönetimi ve Kamu Politikası Yapımı. At <https://setav.org/assets/uploads/2020/06/R165. $p d f>$, accessed 17 October 2020.

Yılmaz, F. H. and Şahin, A. (2018). Sürdürülebilir Çevre için Yeşil Altyapı: Ermenek Özelinde Bir Değerlendirme. At <https://www.researchgate.net/ publication/330997615_surdurulebılır_cevre_ı cın_yesı_altyapı_ermenek_ ozelınde_bır_degerlendırme>, accesse-d 15 October 2020.

Zengin, E., Başkurt, M. and Es, M. (2014). "Yerel Yönetimler ve Yerel Kalkınma". Manas Sosyal Araştırmalar Dergisi, 3(2), pp. 95-124. 